\title{
EchoGéo
}

35 | 2016

Les découpages territoriaux en Europe

\section{Territorial divisions in Europe}

Introduction

\section{Élisabeth Bonnet-Pineau et Christian Vandermotten}

\section{(2) OpenEdition}

Journals

Édition électronique

URL : https://journals.openedition.org/echogeo/14552

DOI : $10.4000 /$ echogeo. 14552

ISSN : 1963-1197

Éditeur

Pôle de recherche pour l'organisation et la diffusion de l'information géographique (CNRS UMR 8586)

Référence électronique

Élisabeth Bonnet-Pineau et Christian Vandermotten, «Territorial divisions in Europe », EchoGéo [En

ligne], 35 | 2016, mis en ligne le 19 avril 2016, consulté le 11 août 2021. URL : http://

journals.openedition.org/echogeo/14552 ; DOI : https://doi.org/10.4000/echogeo.14552

Ce document a été généré automatiquement le 11 août 2021.

EchoGéo est mis à disposition selon les termes de la licence Creative Commons Attribution - Pas d'Utilisation Commerciale - Pas de Modification 4.0 International (CC BY-NC-ND) 


\title{
Territorial divisions in Europe
}

\author{
Introduction
}

\author{
Élisabeth Bonnet-Pineau et Christian Vandermotten
}

1 The study of territorial divisions is expected to fall within the remit of political geography, as it implies an analysis of relations between power and territories as political constructs. However, given the multi-faceted nature of the "territorial paradigm ", we should also look at other approaches to territoriality (M. Vanier, 2010).

2 The articles compiled in this issue tackle territorial divisions from two angles, drawing comparisons between Western and Eastern European states, including countries that joined the European Union in 2004 (Poland) or 2007 (Bulgaria) in the latest rounds of enlargement, as well as Germany and its struggle to meet the challenges of reunification and modernisation.

3 The first perspective looks at the territorial grids established as a result of the emergence of nation-states, and at their contemporary legacy.

4 The concept of the nation-state emerged in the nineteenth century, to meet the needs of economic and political modernisation, at a time when national markets were developing and a form of rationality had been inherited from the Century of Enlightenment. In the early $19^{\text {th }}$ century, the development of the nation-state involved the creation of territorial grids that facilitated political control over territories while supporting a fast-changing economic activity, whose reality was being transformed by industrialisation and rail transport. This process was supported by the production of cultural and ideological frameworks based on a common language and in some cases on the construction of a linguistic identity that attempted to eradicate dialects and regional languages. In Western Europe, the nation-state was often built on the foundation of a lasting and deep-rooted pairing between the state and the territory. In France and England for instance, this close association had been constantly consolidating since the $13^{\text {th }}$ century, with the nation developing as a concept under the Royalty.

5 In this context the archetypal territorial unit, whose uniformity and rationality helped shape centralised states, was the French département (department). A product of the French revolution, it was more or less replicated in many European countries - serving 
as a model for provinces in the Netherlands, Belgium, Spain, Italy etc. The United Kingdom adhered to the same model, although its grid of counties was less homogeneous and retained a greater formal continuity with traditional structures of organisation. In this country the transition occurred earlier, took longer and was less radical than in France where the Ancien Régime gave way to a Parliamentary state.

Belgium provides a unique example in Western Europe of a state that developed later in the $19^{\text {th }}$ century, as the chance result of the bourgeoisie reclaiming control after the people's rebellion. An agreement was passed between neighbouring powers without any truly national initiative, and an unsuccessful attempt was made to create a Frenchspeaking nation. Belgium's history and the part played by merchant cities makes it more akin to central Europe countries. The industrial revolution mostly benefitted the Walloon region while the rural Flanders, more reliant on textile, was declining. However between the two World Wars, the country's industrial production shifted from Wallonia to the Flanders and the past development pattern was altogether reversed after World War Two. This evolution undermined the national construction process, which had already been threatened from the mid-19 $9^{\text {th }}$ century by Flemish independence claims, purportedly based on cultural grounds but also due to economic frustrations. After the 1960s, Belgium went from a unified heritage to embarking on institutional processes that led to the introduction of language-based divisions - to the point where the language border became an intangible internal border in 1962 - and of a conflicted federal regime in 1995 that proceeded to dissolve Belgian identity, although this identity had in actual fact never been fully accomplished.

7 In Central Europe, the legacy of past territorial structures was better preserved. In Switzerland, the traditional division into cantons of varying sizes was never challenged in spite of the creation of a modern state after the Sunderbund war. In other countries, states were formed at a later stage: they were preceded by the development of a national identity, taking in the local power of princes or cities by adopting a federation-based imperial structure, and thus retaining complex divisions inherited from the Ancien Regime until National-Socialism imposed a centralised regime. In both cases, the power of local identities produced a federal structure. However, these structures are the very opposite of what was recently implemented in Belgium following the deconstruction of the unified state. Such a federal organisation involved a strict division of competences between the state and the regions: in Belgium for instance, there is no hierarchy between the state, the Régions (regions) and the Communautés (communities), with each of these entities given sovereignty over relevant issues.

8 In Eastern Central Europe, the creation of the nation-state was not associated with the same economic growth patterns as in Western Europe: this favoured the development of national ideologies grounded in regional identity, as was the case in Germany, or in religion - which is not to say that nationalist movements were not just as vigorous in France or in Great-Britain, although they were built on different ideological grounds.

9 In Poland, before the country became a state and a territorial form, the nation was built upon a culture, a "spiritual homeland" referring to a national space that had been dismembered, reshaped and displaced at the whim of power relations. The Polish territory is a challenge to grasp or represent on a historical scale. After its creation in the $10^{\text {th }}$ century, Poland spread far out to the East between the $14^{\text {th }}$ and $18^{\text {th }}$ centuries, before its territory resorbed when neighbouring powers undertook to share the region 
between them. The Polish nation was shaped around its shared history, language and cultural and religious values. In 1945, with a remodelled configuration and a more homogeneous ethnic make-up, "the new Polish state [had to] develop its territorial integration in a new geopolitical environment" (M. Foucher, 1993).

Contemporary Bulgaria is the heir of the successive Bulgarian Empires that reigned from the $7^{\text {th }}$ to the $14^{\text {th }}$ century. Under the Ottoman rule, political control was based on religious communities as much as on territories ${ }^{1}$. Modern Bulgaria was born in 1878 from a much smaller territory than the one the country had historically ambitioned to control.

11 The difference between Western Europe on the one hand and Central and Western Europe on the other is not just to do with the varying circumstances and ideological foundations of the nation-state: it was also reinforced after World War Two by the implementation of the Soviet spatial system which, in order to impose the centralized management of all economic activity, designed administrative grids to implement and monitor the economic plan. Communist regimes have not however applied a unique administrative model. The legacy of pre-war grids persisted in some cases, although not everywhere. Multiple attempts were made at adjusting territorial divisions to the plan: territorial reform was seen as a means of spreading the planning model. After 1945, the size, role, number and level of territorial districts were in some cases modified up to four or five times: this happened in Bulgaria in 1947, 1949, 1959, 1977 and 1988, and in Poland in 1954, 1975 and 1983. When the iron curtain collapsed, these countries still carried the legacy of this period.

second aspect addressed in this issue covers the recent modifications undergone by territorial grids. These processes are expected to meet the demands of European construction and competitiveness. They also serve the agenda of resurging regional identities, perceived as an alternative to national frameworks that appear less legitimate than ever in the context of current structural modifications.

13 Many European countries have delivered territorial reform programs, bringing about redesigned units and increased devolution to better meet the European union's requirements in terms of territorial cohesion and competitiveness - or, as in Spain, Scotland and Belgium, to satisfy regionalist identity-based claims that have been filling the gaps left by the failings of national legitimacy (see C. Vandermotten). Other smaller-scale reforms have attempted to address the inadequacies of municipal divisions inherited from a society where mobility was more limited. The aim is to make these divisions more operative in the context of general urbanisation and metropolisation, where services are increasingly accessed on a wider scale, creating the need for revised funding models. For instance in France, "territory-making" is extremely popular with national politicians, researchers and experts (M. Vanier, 2010), although paradoxically the actual devolution of competences is much less advanced than in other countries, due to highly centralised territorial structures the country inherited from its past. France's latest territorial reform was voted in 2015 and promulgated in January 2016.

14 In Central Eastern Europe, the need to reorganise competences was associated with a desire to break free from the Communist era grids. This has not however always led to a genuine territorial reorganisation, as was the case in Bulgaria but not in Poland. In the former East Germany, the changes were of course dramatic: the country was 
expected to break free from the Socialist period's spatial markers while embracing West Germany's federal structure, which had been abolished in 1952 to make way for drastic centralisation. The German reunification and the application of Western territorial grids in the East has not prevented a form of marginalisation of the region, even though the equality of living conditions was set out in the new Constitution. This quest for territorial balance remains a considerable challenge in a country with historically strong identities and in some cases traditions of regional independence, especially in areas that did not belong to Prussia but had their own kings such as Saxony or Bavaria.

\section{The consolidation of first level territorial units}

Generally speaking, first level territorial divisions have tended to be consolidated. Over the last few decades, this level was even in many cases built from scratch rather than just reinforced. At the end of World War Two, in unified European states, first level divisions formed a homogeneous web similar to that of the French départements. Larger and sometimes more unevenly sized regions were then superimposed over this level in Italy (with special status regions from 1946), France, Belgium, post-Franco Spain and Poland. In post-war Germany, the return to democracy brought back the Länder (states), which the Nazi regime had replaced with a grid of Gaue from 1934.

This tendency towards the creation of larger first level units, followed by their consolidation (which was more or less pronounced depending on countries) is linked to various objectives. In some cases, it supports (or on the contrary, aims to neutralise) regionalist movements whose political legitimacy has become more established in Spain, Italy, the UK, Belgium and Germany, where such movements had been repressed during the National-Socialist period and during the Soviet era in former East Germany. More recently, first level units have also served the purpose of meeting the requirements of the European Union's territorial cohesion policies: the Union boosted the regional support programmes of the past and since 1999, it has worked to promote convergence by reducing development gaps between the Union's states and regions. Finally, large metropolises want to carve a place for themselves in the international competition between territories by organising and supporting the development of larger metropolitan areas.

This "augmented first level" was an obvious choice in Germany: it was built upon the federal states' strong identity but also upon a multi-centric structure, with regional centres based on the even allocation of Metropolregionen (metropolitan regions) across the territory - although a dissymmetry still persists between the East and the West: it was logical to apply this structure in the East too.

In Italy, the consolidation of the first level also drew from a tight network of cities, although a North vs. South dualism remains visible in the opposition between Milan and Rome, without mentioning Naples or Palermo. From as early as 1948, Italy defined itself as a regional state, "rebuilding democracy through the territory" (D. Rivière, 2014). The Christian democrats controlled every scale until 1980: it was not until the 1990s that Italy was able to consolidate its regional, municipal and metropolitan authorities, whose legitimacy was reinforced by the failure of the state. The rise of the regions is directly correlated to the intensification of devolution. It is based on traditions linked to regional identity, which has persisted due to the country's late unification and thrived from blatant regional inequalities. However, in 2014-2015, metropolises were created under the impulse of the central state to better control the 
regions and limit the influence of the Senate, which represents the regions (see D. Rivière).

In Spain, assertions of regional identity were liberalised at the fall of Franco and gave rise to independence claims in Catalonia and the Basque country.

Similar claims led to a form of "separatist" federalism in Belgium. The survival of this model survival appears mostly due to the fact that the capital is at the heart of the country's economic activity, while its area of influence is split between regions that lay outside of the metropolis' control.

France also attempted to bring the regional level more recognition, in order to better meet European requirements aimed at consolidating the interplay between regions and the European Union. Another aim was to compensate for the state's general tendency to withdraw from territorial planning and development, in an increasingly neo-liberal environment. However, it seems that the country interrupted this process halfway through. The devolution process initiated in 1982 and re-launched in 2004 mostly enabled the central state to offload responsibility by transferring areas of competence onto the local echelons, rather than defining new models of interaction and coordination between levels of management, or between political and administrative functions (see E. Bonnet-Pineau).

France's regional reform (law of the $16^{\text {th }}$ January 2015) was designed to equip the country with a new territorial architecture by creating large regions and generating competitiveness gains. Another objective was to clarify the territorial authorities' respective areas of competence. However, although reducing the number of regions was relatively easy (without it really achieving any of the intended efficiency gains in a demonstrable manner), suppressing the départements is not easy, as those remain a local echelon that grants the population access to national solidarity. The redesign of the regional map was in fact achieved by merging existing regions together, without affecting any of the départements that make up these regions.

The review of missions and the devolution of powers did not either bring about a reorganisation of each echelon's remit, or an increase in the regions' budgetary capacity or decisionary power. The allocation of roles and fields of action between the various echelons contradicts the very principle of territorial development, according to which a region should be able to be involved in every sector. Finally, the financial conditions required for the completion and long-term follow-up of projects have remained undefined, jeopardising the reform's ability to achieve its initial objectives.

The law of the $27^{\text {th }}$ January 2014 for the modernisation of territorial public action instated metropolises in Paris, Lyon and Marseille while setting out the modalities for a new metropolitan governance. This law is an invitation to question the state's role in metropolitan governance, and question the relation between metropolises and regions. This construction was challenging in the case of Paris, where it was affected by political, economical and financial factors: as a capital, Paris needs to establish its relations with both the state and the Île-de-France region.

This issue does not unfortunately contain any articles about the United Kingdom, which remains Europe's most centralised country, with an inconsistent management of the regional echelons - to the exclusion of the powers devolved to Scotland, Wales and Northern Ireland. 

Bulgaria. in Switzerland.

\section{The local scale}

This issue of the relations between the capital city and the rest of the territory is particularly acute in Central Eastern Europe. In these countries, due to the effects of globalisation combined with the consistently poor levels of power granted by socialist regimes to first level urban grids, the capitals have remained the regions that enjoy the best connection with the European space, and in a position to grow their advantage over the rest of the country: this is for instance the case of Varsaw in Poland, or Sofia in

In Central Eastern Europe (except for the former East Germany), in spite of territorial reforms and a stated willingness to consolidate the regions' powers, the first level has remained weak. This is due to the lack of a tradition of devolution, even before the Communist regimes were in power, and to the reluctance of recently formed states, whose main priority remains to assert their external borders. In Poland, the number of voivodies was brought down to 16 in 1999, in an attempt to consolidate this first level. In Bulgaria however, the part played by the regions remains inconsistent due to the weakness of large regional cities, to the absence of historical regions and to the restriction of the regions' remit to the sole coordination of local and national interests, even though these units have control over the municipal echelon (see E. Boulineau). The regions were mostly created to satisfy EUROSTAT's demands in terms of statistics but as a matter of fact European funds have only trickled down to the medium echelons, before being suspended due to fraud and corruption.

\section{Mid-level divisions}

Most European countries, except for the very smallest, have a mid-level echelon in between first level and local units.

This intermediate level has very little leverage in federal states: this is the case in Germany with the Regierungsbezirke, which only exist in the largest states. In Belgium, province-level responsibilities have declined - in Wallonia even more so than in Flanders - while Brussels now sits outside of this system. There is no intermediate level

The situation is similar in decentralised states, where the very existence of an intermediate level (formerly the known as provinces) is being challenged. In Italy this echelon is doomed to disappear to make way for regions and metropolises; in Spain, autonomous "communities" have taken over the provinces. Catalonia even created its own intermediate level, the comarcas, to challenge the legitimacy of the provinces which are seen as a relic of the central state's dominance (see E. Libourel).

Finally, the former first level unit of the department continues to exert its power in France, thus reflecting the shortcomings of regional divisions.

In Central Eastern Europe, the intermediate level is usually of little importance. In Poland for instance, the 380 powiats (districts) located in between the voïvodies and the 2 478 municipalities have very little leverage (see T. Kazmarek).

The local scale has often been more stable in the long term, although many countries have merged their municipalities over the last decades.

In general, comparisons show a greater heterogeneity between local administrative districts than between municipal grids. In some countries such as the UK, local services are scattered between various authorities; in others, city authorities are closely 
monitored by central institutions and are seen as a mere instrument for the provision and organisation of administrative services - this was the case for instance in Central Eastern Europe during the Communist period. In Switzerland on the contrary, ancestral belonging to a municipality forms the very foundation of national citizenship, while in Belgium municipalities benefit from a high level of autonomy. They also play a prominent part in Italy's recent political history, so much so that "exacerbated municipalism" has been mentioned as an issue when, in the 1990s, the Lega del Nord introduced its brand of "aggressive regionalism" (D. Rivière, 2015).

A table of local administrative units in the European union (see J.-B. Grison) shows France's singularity, with a high number of very small districts inherited from the Ancien Régime's paroisses (parishes), which resisted to merger attempts. Yet as a matter of fact, these municipalities are less autonomous from central authorities than in other countries. The French's attachment to these local districts explains their power of inertia and longevity. Clusters of municipalities (or intercommunalité) has become the norm, providing a compromise solution to avoid conflict with the towns and their representatives while creating structures large enough to deliver and rationalise services to the population. In recent years, financial incentives have also been created to encourage smaller towns to merge together.

Paradoxically, Belgian communes, whose foundation followed the same model as the French municipalities, underwent a general merger process in 1976, while at the same time local authorities were granted stronger powers. Unlike in France, the local grid does not always lie under the state's responsibility: in Belgium, the network of municipalities is supervised by the regions. It is managed by the federal states in Germany, where the grid has been redesigned more or less drastically depending on the individual states: in Rheinland-Palatinate the municipalities remained fragmented; in North Rheinland-Westphalia, they were merged; in Saxony-Anhalt, the ex-GDR's most urban state, the municipalities' borders were redesigned in order to rationalise territorial organisation for the benefit of central spaces, following the same pattern as in North Rheinland-Westphalia (D. Florentin).

England's centralism excludes any consistency on a regional level. The complexity and heterogeneity of the local grid together with the proliferation of government agencies highlight the central government's stranglehold, which has been further reinforced by Conservative governments whose opponents are mostly concentrated in large cities. In this paradoxical country, the diversity of structures actually hides a centralised system - while on the contrary, in French-influenced continental countries, centralisation was imposed through homogenisation.

41 The most striking aspect of the mutations undergone by Central Eastern Europe is the local authorities' return to autonomy. This was implemented in Poland through the territorial reforms of 1990, 1999 and 2011. In Bulgaria the 1999 reform, seen as a "pseudo-reform", was completed in 2007 with a modification of the Constitution that granted municipalities greater fiscal autonomy. The introduction of new devolved funding channels for local authorities was in some cases conditional to mergers between local entities, as illustrated by Saxony. Paradoxically, while in Central Eastern Europe municipalities had lost their autonomy during the Communist period, local divisions had remained relatively stable.

42 To conclude, although there is unquestionably a dialectical interaction between on the one hand management models and political/administrative divisions, and on the other 
hand the production of space in its economic, social and cultural dimension (although the two aspects, which follow timescales of their own, are never quite balanced). Politicians sometimes overstate the real impact of territorial reorganisation on the evolution of space. For instance when the Jacobin revolutionaries punished Lyon by making it the préfecture of a considerably shrunk down département, this did not stop the city from becoming France's second largest metropolis. Outside of Europe, the emergence of new capitals built straight out of the ground never posed a threat to large metropolises, which had been historical capitals and remained the main economic centres. In Belgium, the metropolisation of the central area around Brussels is still under way, in spite of political decisions deliberately aimed at constraining the capital's growth - even when these decisions make territorial management more difficult (C. Vandermotten). As a matter of fact, the willingness to rationalise territorial management and reorganise territories according to patterns designed to make them more competitive, more efficient and better prepared to meet globalisation's financial challenges is based on the assumption that territories have the inner capacity to act as a regulating and driving force. Nevertheless, territories do not intrinsically hold such abilities: they are subjected to circumstances such as the inertia of inherited structures and to multiple decisions from stakeholders whose motives are often far from political.

\section{BIBLIOGRAPHIE}

Foucher M., 1993. Fragments d'Europe. Fayard.

Rivière D., 2014. L'Italie de la crise. Les cafés Géo (www.cafe-geo.net/litalie-de-la-crise)

Vanier M., 2002. Recomposition territoriale française : la voie française. L'information

géographique, p. 99-112.

\section{NOTES}

1. This idea can also be found, in a more modern and secular form, in pre-first world War AustroMarxist projects to organise the Austro-Hungarian Empire into federations based on autonomous ethnic communities rather than territories.

\section{INDEX}

Thèmes : Sur le Champ - Sur le Terrain 
AUTEURS

\section{ÉLISABETH BONNET-PINEAU}

Elisabeth Bonnet Pineau, danieloster@wanadoo.fr, is a geographer and a consultant.

\section{CHRISTIAN VANDERMOTTEN}

Christian Vandermotten cvdmotte@ulb.ac.be, is a Professor at Brussel's Université Libre and a member of the Royal Academy of Science, Letters and Fine Arts of Belgium. 